\title{
Introduction to this edition
}

\author{
MARLISE RIJKS
}

\begin{abstract}
'He will seem to you a simple farmer, but one must not be misled by appearances. [...] This person is Dirk Rembrantsz van Nierop, who learned about the phases of the Heavens while patching shoes ${ }^{1}$
\end{abstract}

In 1701 writer and engraver Romeyn de Hooghe (1645-1708) published a peculiar pamphlet entitled De Italiaansche waarzegger. Esopus, Antonio Magino, en Dirk Rembrantsz van Nierop ('The Italian fortune-teller. Esopus, Antonio Magino, and Dirck Rembrantsz van Nierop'). In this pamphlet, three unlikely characters are put together on stage: Esopus, writer of the ancient Greek book of fables; Antonio Magino, a sixteenth century professor of mathematics in Bologna; and Dirck Rembrantsz van Nierop, a seventeenth-century shoemaker, autodidact mathematician, as well as astronomer, from an obscure village in the north of Holland. This pamphlet raises all kinds of questions on the image of astronomy, astrology and mathematics in the early eighteenth century. What are the characters representing? And who was Dirck Rembrantsz van Nierop? What is the story behind this seventeenth century shoemaker who trained himself in astronomy and became so famous that he was used as a character in a pamphlet twenty years after his death?

Writer and engraver Romeyn de Hooghe wrote all kinds of pamphlets on subjects ranging from politics to natural philosophy and mathematics, published together in Esopus in Europa. De Hooghe introduces the character of Esopus to

\footnotetext{
1 'Hy komt u slegt, als een Boertje voor, maar aan het uiterlijk moet men zich nooit vergaapen, [...] Deze is Dirk Rembrantsz van Nierop, die onder het schoenen lappen zoo vast in de Hemels loop was, dat zyn kamertje, met Konstlinien doortrokken, te Florense zou staan, was het zo licht door de lugt te voeren, als de Kapel van Lorette'. Cf. De Hooghe, De Italiaansche waarzegger. Esopus, Antonio Magino, en Dirk Rembrantsz van Nierop (1701), 4.
} 
ridicule the astronomical knowledge of Antonio Magino and Dirck Rembrantsz and their supposed claims as fortune-tellers, since astrological predictions were widely available in all kinds of popular almanachs. ${ }^{2}$ Esopus compares Magino and Rembrantsz to the 'oracle priests' of ancient Greek. Magino replies that, instead of telling fables, astronomy and astrology provide 'prognoses' for the future. Esopus then tells a story about birds, adorning themselves with the plumes of other birds, which ends in fighting and the unmasking of the 'fake' birds. On the background of the title page engraving, we can see the fighting birds, which are interpreted as fighting kings but - when reading the Esopus' fable - can also be interpreted as a moral: do not pretend to be something one is not. The themes of rivalry (and rival knowledge) and 'to adorn oneself with borrowed plumes' must be understood in a seventeenth century context where mathematical and astronomical knowledge were at the forefront of all kinds of developments in society.

\section{Dirck Rembrantsz van Nierop and knowledge in the Dutch Republic}

Dirck Rembrantsz van Nierop (1610 - 1682) started his extraordinary career as a simple shoemaker, but became a well-known mathematician, navigation teacher, and astronomer in the Dutch Republic. He usually signed his letters with his first name and patronym, Dirck Rembrantsz, indicating his modest origin, only adding Van Nierop (after his birth place Nieuwe Niedorp) to his name later in life. Despite his modest background and the fact that he did not master any foreign language, he was respected for his bright insight and mathematical knowledge by learned men such as Christiaan Huygens, René Descartes, Frans van Schooten the younger, Johannes Hudde and Nicolaas Witsen. Due to his preserved correspondence we have an unique insight in Dirck Rembrantsz' life and, perhaps more important, in the 'knowledge society' of the seventeenth century Dutch Republic.

Dirck Rembrantsz' correspondence has been made available as a part of the open source project 'Circulation of Knowledge Collected Corpora' (CKCC), by the Huygens ING. His corpus will be one of the corpora included in a digital database of scholarly correspondence. In 1996 Rienk Vermij has published an article

\footnotetext{
${ }^{2}$ On Dutch Almanachs in the seventeenth century, see: Salman, Populair drukwerk in de Gouden Eeuw. De almanak als lectuur en handelswaar (Zutphen, 1999).
} 
in Lias on the correspondence of Dirck Rembrantsz van Nierop, included here with the authorisation of the author. ${ }^{3}$ In this paper, Vermij provides a short introduction to the life and work of Dirck Rembrantsz, an overview of his correspondents and an English translation of a selection of letters. In the introduction to this edition, I will further elaborate on Dirck Rembrantsz' meaning for the history of science, his place of origin and family relations, his national and international network of correspondents, the meaning of his letters in relation to his books as an illuminating example of the circulation of knowledge, and the reception of his work after his death.

The correspondence of Dirck Rembrantsz has been passed down to us in a remarkable roundabout way (on which more below). His letters provide a very rare insight into the milieu of practical mathematicians and artisans in the seventeenth century. During the last decades historians of science have debated the traditional dichotomies of knowing and doing, of theory and practice, and of scholars and artisans. ${ }^{4}$ For an understanding of knowledge in historical perspective it is necessary to integrate 'great, revolutionary ideas' and 'tacit knowledge' - or to focus on the relations between the great minds, mediocre scholars, and 'invisible technicians'. Dirck corresponded with famous scholars, but also with captains, lens-grinders, surveyors, publishers, ministers, governors, and 'connoisseurs of the mathematical arts'. The letters in this edition are an exceptional remain of otherwise ill documented personal contacts between all kinds of persons interested in new knowledge.

The connection between the so-called 'Scientific Revolution' and international networks of trade and exchange has also come into the focus of

\footnotetext{
${ }^{3}$ Vermij, 'Correspondence of Dirk Rembrandtszoon van Nierop' (1996); reprinted in this edition.

${ }^{4}$ See for example: Roberts, Schaffer and Dear (eds.), The Mindful Hand. Inquiry and invention from the late Renaissance to early Industrialization (2007).

${ }^{5}$ Shapin, 'The invisible technician' (1989).

${ }^{6}$ One of them was the well-known mayor of Amsterdam Nicolaas Witsen, who expresses his admiration for Van Nierop. 'Ik heb al lange Jaaren verwonderaar geweest van uwe wetenschappen, en der schrifte die met de druk gemeen gemaakt zyn veel maalen bespiegelt en geleezen'. ['For many years I have been an admirer of your sciences, and your published writings I have reflected upon and read many times']. This edition letter nr. 60: Witsen to Dirk Rembrantsz, 15 Jan. 1679.
} 
historians of science recently. ${ }^{7}$ The relation between mercantile values and the emergence of new science is manifested for example in navigational knowledge (Dirck Rembrantsz worked as a navigation teacher), which was vital to the Dutch trade with the East and West Indies and the Baltic. Dirck Rembrantsz' corpus of letters presents a beautiful example of the combination of theoretical and practical knowledge: we read about issues ranging from the Copernican system, the use of instruments, to sailing routes along Nova Zembla. ${ }^{8}$ Illustrative are correspondents who in their person combine mercantile and scientific interests, such as the geographer-cartographer Nicolaas Witsen, who later in life became one of the directors of the Dutch East India Company (VOC).

Dirck Rembrantsz' correspondence shows the widespread interest in the new 'natural philosophy' and 'practical mathematics' in the seventeenth century Dutch Republic. His entire life he lived in the small village Nieuwe Niedorp in the north of Holland, but was able to write and publish many books and keep up a partly international correspondence. In the Dutch Republic knowledge was not just the privileged area of university professors. Merchants and magistrates as well as lower ranked captains and instrument makers were interested in new (mathematical) knowledge about nature and played their part in the circulation of knowledge and practices. Mathematical knowledge was useful in many ways, but could also be a means to increase one's social status. More and more, practical and theoretical knowledge became interwoven with the economy, arts and politics, perhaps making the Dutch Republic in the seventeenth century a 'laboratory of the Scientific Revolution'.9

Dirck Rembrantsz was born in the same year in which Galileo published his well-known Siderius Nuncius (1610), the first account of observations of the

\footnotetext{
${ }^{7}$ For example by Cook, Matters of Exchange (2007). Cook focuses mainly on trading networks with the East and West Indies in relation to natural history and botany, while neglecting the role of practical mathematics and other trading networks.

${ }^{8}$ On this particular subject, Van Nierop's fame even reached England. See: 'A Narrative of some Observations made upon several voyages, undertaken to find a way for sailing about the North to the East-Indies, and for returning the same way from thence hither [...] Englished by the Publisher out of Dutch; which had been compos'd by Dirick Rembrantz van Nierop, and printed Amsterdam 1674, in 4', Philosophical Transactions (1674) 197-208.

${ }^{9}$ Van Berkel, 'The Dutch Republic. Laboratory of the Scientific Revolution' (2010).
} 
Heavens with a telescope. Like Galileo, Van Nierop adhered to the Copernican worldview, as for instance is pointed out in Van Nierop's book Eenige oeffeningen (1669). ${ }^{10}$ From his correspondence, it is noticeable how often the work of Copernicus is discussed, just as the work of Ptolemy and Tycho Brahe. Yet there is not a single reference to Galileo! It is striking that Van Nierop makes no references to the telescopic observations of Galileo, indicating that he was more interested in theoretical models and mathematics than in observations. Van Nierop most likely owned a telescope, and his letters and books show some evidence of interest in astronomical observations, but these are scarce remarks amongst a vast corpus of mathematical models. Although Galileo's Siderius Nuncius was never translated in Dutch, it is still remarkable that Van Nierop does not discuss Galileo's observations with any of his correspondents. The work of Johannes Kepler for instance, is discussed by Van Nierop and his correspondents. However, by far the most discussed person in Dirck Rembrantsz' corpus is René Descartes: in fourteen different letters, compared to Brahe in nine, Copernicus in seven, Ptolemy in three and Kepler in two letters. When Descartes was living in Egmond (in the years 1643 - 1649), Van Nierop had frequently visited the natural philosopher (on which more below) and had become an adherent of the Cartesian world view. In the letters Dirck Rembrantsz defends his Cartesian and Copernican worldviews to everyone interested in the 'mathematical arts'.

In the seventeenth century letters formed an indispensable part of the dissemination of knowledge, which is abridged by the concept 'Republic of Letters'. Before the emergence of scientific journals (in 1667), new knowledge was communicated by exchanging letters. New claims were debated and contested in letters, also over long geographical distances. Dirck Rembrantsz' correspondence is a significant source because it demonstrates how he spread knowledge provided to him by sailors and captains coming back to the Dutch Republic from travels all over the world. Besides, Van Nierop used many letters in his books (for instance letters by Huygens and Hudde): underscoring the close relationship between his correspondence and publications. Circulation of knowledge can hardly be more visible.

${ }^{10}$ Dirck Rembrantsz van Nierop, Eenige oeffeningen in God-lijcke, Wis-konstige en Natuerlijcke dingen (1669) 6. See: Hoogendoorn, Bibliography, nr. 19. 
In the early modern period there was almost no distinction between personal letters, polemic pamphlets, and aloof books. Exemplary is the title of one of Van Nierop's books: Antwoort op den brief van Jacob Coccaeus ('Answer to a letter by Jacob Coccaeus'). ${ }^{11}$ A closer investigation of this publication reveals that this book of 47 pages was a text that was never sent as a genuine letter, neither was Jacob Coccaeus' 'letter'. The polemic character of this book is revealed instantly: before disputing Coccaeus ideas in the main text, Van Nierop started with a short doggerel wherein he ridicules Coccaeus as being 'blind and asleep'. He rhymes that 'the arts (it is true) are bound to neither time nor place' and therefore one should not 'reject the old, firmly established' and the works 'of sturdy ingenuity'. Those who 'deny all that is common, to try something new themselves' and 'do not found and substantiate their acts well' must be 'blind and asleep'. 12

\section{Pamphlets and plagiarism}

In a society where knowledge played an increasingly important role, struggles over true and appropriate knowledge increased simultaneously, while sceptics were doubtful about the value of new knowledge in general. Understanding these struggles - and understanding the circulation of knowledge and practices - requires looking at knowledge claims in books, pamphlets and letters, and asking how different means of communication were used and intertwined. The aforementioned pamphlet by Romeyn de Hooghe is an illustrative example of the ridiculing of mathematics, astronomy and astrology in a literary form.

Ridiculing and disclaiming the knowledge and books of others was not uncommon amongst mathematical practitioners themselves in the second half of the seventeenth century. The well-known 'pamphlet-battle' of the Amsterdam mathematical practitioners in 1663-1664, started by a certain Cornelis van Leeuwen,

\footnotetext{
${ }^{11}$ Dirck Rembrantsz van Nierop, Antwoort op den brief van Jacob Coccaeus (1661). See: Bibliography, nr. 17. This work is a response on the work by Jacob Coccaeus, Epistola de mundi,(1660), translated into Dutch by I. Kies van Wissen as Brief over de t'samen-stellinghen des werelts (1660).

12 'Aan den Leeser / De kunsten ('t is waer) aen tijt noch plaets gebonden, / Daer hoeft ook niet gevraeght, by wien het is gevonden: / Maer wie een oude vond, die vast en wel gestelt, / Van kloeck vernuft getoetst, en snedigh breyn verselt, / Wil werpen wech om veer, verstooten en verachten, / Ja al 't gemeen ontkent, om selfs wat nieus te trachten: / So die zijn doen niet wel, en vast heeft onderstut, / Hoe kan die anders zijn als blint en in den dut? / D.R.V.N.'. Cf. Van Nierop, Antwoord op de brief van Jacobus Coccaeus (1661) 4.
} 
was an example of a struggle fought out in books, pamphlets and letters. The most important issue of this battle was the accusation of plagiarism, which can be interpreted as a battle for expertise. ${ }^{13}$ Van Leeuwen was very critical of those priding themselves on the knowledge or findings of others, or 'to adorn oneself with borrowed plumes'. ${ }^{14}$ In later years the theme of birds adorning themselves with borrowed plumes was likewise used by De Hooghe. It is not unlikely that De Hooghe also mocked the 'pamphlet battle' among mathematical practitioners in his own pamphlet. Another example is the playwright by Pieter Langedijk De Wiskunstenaars, of 't gevluchte juffertje (The mathematicians, or the runaway young lady) from 1715, in which mathematical practitioners debate various mathematical issues and do not shun swearing and insulting each other. ${ }^{15}$

Dirck Rembrantsz van Nierop became involved in the 'pamphlet-battle' because Cornelis van Leeuwen accused Abraham de Graaf of plagiarizing Van Nierop's work. Abraham de Graaf, an Amsterdam mathematician and perhaps a former pupil of Van Nierop ${ }^{16}$, had apparently copied some of Van Nierop's tables. De Graaf responded to the claims of plagiarism in a letter to Van Nierop, published in the appendix of his book Ontleding van de bril voor de Amsterdamze belachelijke geometristen (1663). ${ }^{17}$ We do not know whether this letter was actually send to Van Nierop, but because both De Graaf's letter as well as Van Nierop's answer are published in a letter structure, and to illustrate the fluid borders between letters, pamphlets and books described above, they are included in this edition. ${ }^{18}$ Moreover, the letters between De Graaf and Van Nierop concern a genuine debate, unlike the

\footnotetext{
13 Nicolaye, 'Dwaasheid of retoriek? Cornelis van Leeuwen en de 'Belachelijke Geometristen" (forthcoming).

14 '... met andere vogels haer veeren gaen swetsen'. See: Van Leeuwen, School-boeck der wynroeyeryen (1663) fol. ^2r. Quoted in: Nicolaye, 'Dwaasheid of retoriek?' (2012).

${ }^{15}$ Langendijk, De Wiskunstenaars, of 't gevluchte juffertje (1715). See also: Wolthuis, 'Pieter Langendijk en de wiskunstenaars' (1936); Zuidervaart, Van 'Konstgenoten' en hemelse fenomenen ( 1999), 19-20; Nicolaye, 'Dwaasheid of retoriek?' (2012).

${ }^{16}$ See this volume, letter nr. 7.

${ }^{17}$ De Graaf, Ontleding van de bril voor de Amsterdamze belachelijke geometristen (1663). In this book, De Graaf also includes a letter to Cornelis van Leeuwen, 53-55.

${ }^{18}$ In this edition: letter nr. 29 and 59. See also: Dirck Rembrantsz van Nierop, Byvoeghsel op des aertryks beweging of de sonne silstant (1677). [Bibliography, nr. 27].
} 
published 'letter' by Van Nierop to Coccaeus, who never cared to respond to Van Nierop. ${ }^{19}$ Dirck often copied letters or fragments of letters in his books, which might have happened to the letter to De Graaf, especially since the letter was only published in 1677, fourteen years after the De Graaf's original letter. In this particular letter Van Nierop writes that De Graaf copied some tables and figures, and even a printing error - a very convincing proof of plagiarism. However, Van Nierop himself admits that some of the figures copied by De Graaf, were in fact copied by him after an original figure published by Descartes. ${ }^{20}$

It is difficult to determine the meaning of plagiarism in the seventeenth century. Often authors signed every printed copy of a book to guarantee its authenticity. The States-General of the Dutch Republic, or their provincial counterparts, sometimes granted a 'privilege' to authors to publish exclusively on specific matters; Pieter Rembrantsz van Nierop for example, Dirck's nephew and successor, was granted a privilege by the State of Holland to publish calculations on the phases of the moon and the calculation of the tides. ${ }^{21}$ These control mechanisms were far from watertight; regulating and controlling authenticity and originality remained problematic. Besides, the norms to determine what counted as plagiarism, were less strict than nowadays, which is vividly demonstrated by drawings and figures that were almost exactly copied from one book to the other. As Van Nierop admitted in his 'letter' to De Graaf, he was also 'guilty' of publishing figures that were very much like the ones published by Descartes.

\footnotetext{
${ }^{19}$ From his auction catalogue we know that Jacob Coccaeus owned an impressive book collection, but he had no books by Van Nierop. (In his library were works of, among others, René Descartes, Frans van Schooten, Jan Jansz Stampioen, Philip Lansbergen, and Anthoni Smyters.) Besides books, Coccaeus also owned 'Twee paer Globen; Twee Verre-kijckers [added in handwriting:] de grootste 11 voet 6 - -; Twee Mucroschopien; Een gewapende Zeyl-steen, en twee ongewapende; Eenige seer rare geslepe Glasen'. ['two pair of globes, two telescopes (the largest 11 feet), two microscopes, lodestone, some rare grinded lenses'] Auction catalogue of Jacob Coccaeus, 1672. Original: Wolfenbüttel, HAB Bc Kapsel 2:12.

${ }^{20}$ Letter 59 [this edition]: 'Figuer oock uyt het mijne, of ghelijck ick die van Des Kartes na gemaeckt hadde'.

${ }^{21}$ Patent of 22 September 1693. See this volume: 'Appendix’ A-5.
} 

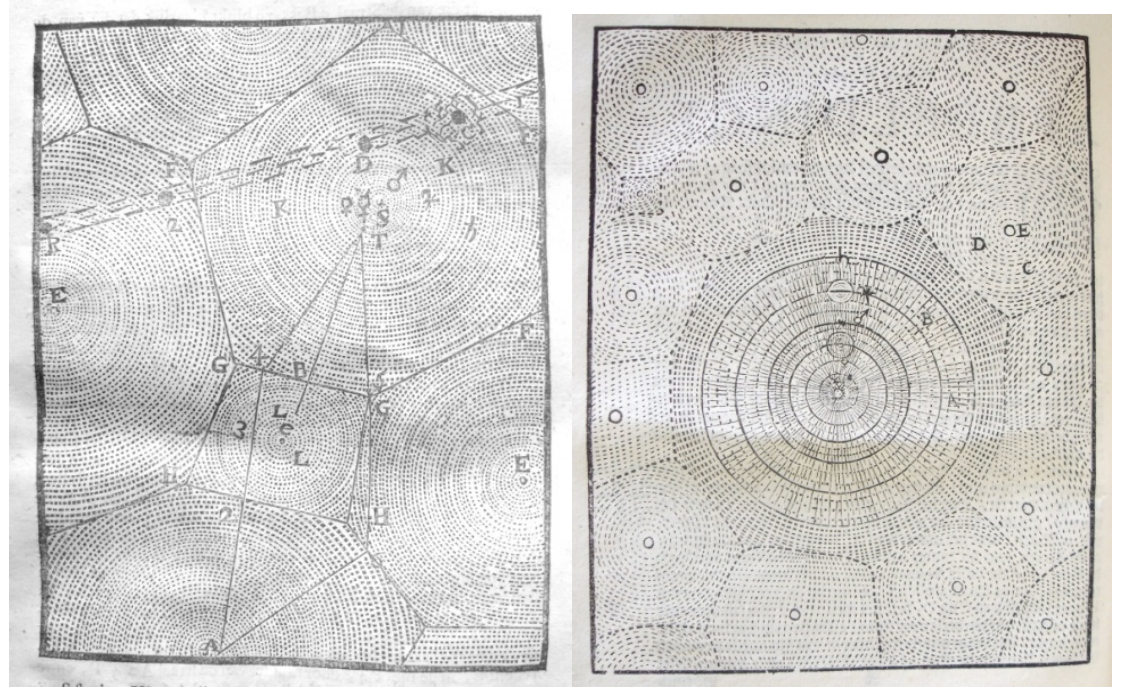

Left: Descartes, Principia Philosophia (1644)

Right: Van Nierop, Nederduytsche Astronomia (1653)
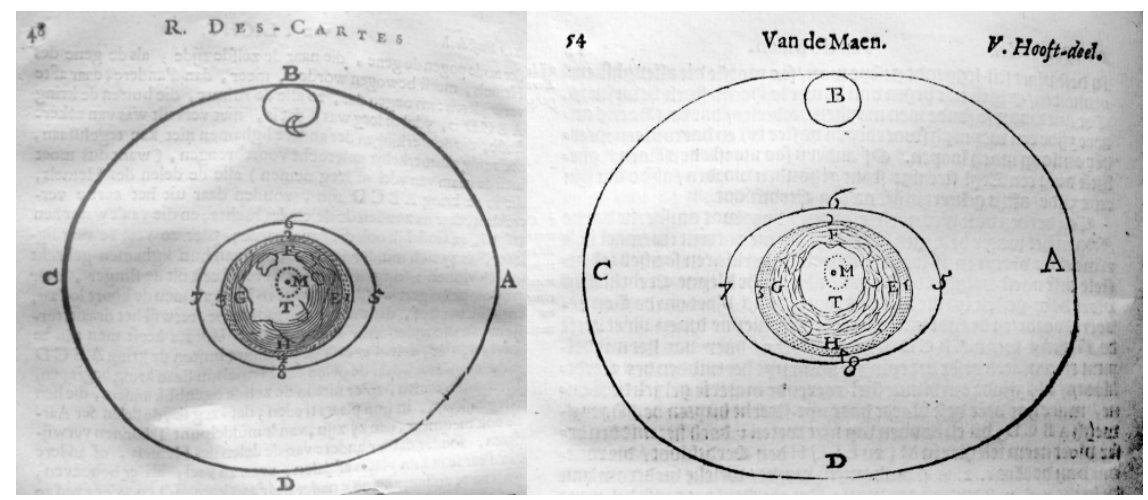

Left: Descartes, Principia Philosophia (1644)

Right: Van Nierop, Nederduytsche Astronomia (1653) 


\section{Almanachs and patents}

The States of Holland and West-Friesland could grant patents for new inventions and the exclusive privilege to publish on certain matters, for instance to publish almanachs. Almanachs with the tides and the rising and setting of the moon were of vital importance to the shipping trade, while until far into the eighteenth century fables and astrological predictions were often included in almanachs too. Standard and well-known were the astrological predictions by Antonio Magino, the Italian astronomer ridiculed by De Hooghe. ${ }^{22}$ Almanachs were hugely popular for practical reasons and entertainment. ${ }^{23}$ With his almanachs, Dirck Rembrantsz' fame was extended to layers of the population otherwise uninterested in mathematics or astronomy.

Van Nierop apparently had never applied for the exclusive patent to publish on the calculations of the rising and setting of the moon, because his authority was undisputed. ${ }^{24}$ Yet immediately after his death, a patent was requested by Isaac Haringhuysen (1640 - 1692), a surveyor and mathematical practitioner in Alkmaar. ${ }^{25}$ In March 1676 Haringhuysen already had obtained a patent to publish exclusively a table with information on the tides. A table with similar information on the times of rising and setting of the moon had been composed since the 1650's by Dirck Rembrantsz. Now this famous mathematical practitioned had passed away, Haringhuysen wanted to extent his 'privilegie' with a similar patent on Dirck's former business: the rising and setting of the moon. Remarkably this 'privilegie' was granted to him only three weeks after Dirck's death (on 28 November 1682), taking Dirck's nephew and successor Pieter Rembrantsz van Nierop quite by surprise. When in November 1683 the Amsterdam publisher Gillis Joosten Saagman announced his plans to issue an almanach with tables concerning the moon, calculated by Pieter Rembrantsz van Nierop, Saagman immediately was summoned

\footnotetext{
${ }^{22}$ For example included in an Alkmaar Almanach of 1710: the sixth quire consists of De Magino's predictions (the fifth quire includes a method by Van Nierop to calculate the tides). Cf. Van Eeghen, 'De Stichter's Enkhuizer Almanak en Amsterdam' (1983), 43.

${ }^{23}$ See: Salman, Populair drukwerk in de Gouden Eeuw (1999).

${ }^{24}$ Van Eeghen, 'De Stichter's Enkhuizer Almanak en Amsterdam’ (1983), 34.

${ }^{25}$ See this volume, document A-4.
} 
by Haringhuysen to withdraw his plans. ${ }^{26}$ In the end a settlement was reached, with the result that in 1685 Saagman produced two almanachs: one with Haringhuysen's tables and another with those calculated by Pieter Rembrantsz. ${ }^{27}$ But eventually Pieter had no other choice than to assist Haringhuysen in his almanach production. Until Haringhuysen's death, in 1692, some of their joined work was published as Haringhuysens Nieropper Almanach. Bus as soon as Haringhuysen had died, Pieter Rembrantsz requested for a patent of his own. This indeed was granted to him, as was the 'privilegie' to exclusively re-publish the works of his uncle Dirck. ${ }^{28}$

After Pieter Rembrantsz' death the patent to publish the calculations of the rising and setting of the moon and the calculation of the tides, as well as the patent to publish the works of Dirck and Pieter Rembrantsz, was granted to Jan Albertsz van Dam, son of Dirck Rembrantsz' nephew-by-marriage Albert Jansz van Dam. In this way the publishing of almanachs and the revenues of the earlier works remained within the family for another generation. ${ }^{29}$ In the charter it is stated that the patent is supplied to Jan Alberstz because of the risk that other - ignorant - persons could wrongly copy almanachs, which could lead to 'grove misstellinge' (gross errors) and 'groote onordentelykheden' (great turmoil). Jan Albertsz was granted the patent for fifteen years, with anyone violating the privilege compelled to pay a fine of 300 guilders, of which one-third was for the official involved, one-third for the poor and one-third for Jan Albertsz himself. ${ }^{30}$ Similar patents were granted to the Van Dam family in 1724, 1743, 1756 and 1780, until the abolishment of the patent system with the end of the Dutch Republic in 1795.

\section{A shoemaker in a humble village?}

Romeyn de Hooghe gives a telling description of Van Nierop in De Italiaansche waarzegger, portraying him as a 'simple farmer' who 'learned astronomy while

\footnotetext{
${ }^{26}$ Hazewinkel, 'De oudst bekende Rotterdamsche almanak' (1933), 22-23.

${ }^{27}$ Van Eeghen, 'Ambachten en beroepen voor almanakjes' (1982), 111.

${ }^{28}$ See 'Appendix' A-4 \& A-5. See also Van Eeghen, 'De Stichter's Enkhuizer Almanak en Amsterdam' (1983).

${ }^{29}$ Jan Albertsz van Dam was the son of Albert Jansz van Dam, Dirck's nephew-by-marriage. See also this volume, Zuidervaart 'The Van Nierop \& Van Dam dynasty of mathematical practitioners'.

${ }^{30}$ See this volume: 'Appendix' A-6.
} 
patching shoes'. ${ }^{31}$ To a certain extent this portrayel of Dirck Rembrantsz was true. Van Nierop had no formal education and lived in his birthplace all his life, the small village Nieuwe Niedorp in the countryside of Holland, with only 1616 inhabitants and 316 houses (in 1622). ${ }^{32}$ The humble state of people in West-Friesland - the north-western part of Holland where Nieuwe Niedorp is located - was described by a local inhabitant of the region Reyer Dircksz to chronicler Jan Adriaensz Leeghwater. In the village of Langedijk (less than $10 \mathrm{~km}$ from Nieuwe Niedorp) for instance, there were only three pairs of shoes, which were reserved for the regents of the village, when they had to travel to the States General in The Hague. In daily life every one used clogs ('klompen'). ${ }^{33}$ This also points to the rarity of shoes in the seventeenth century, a luxury product, which indicates a certain status of the profession of shoemaker. Another revealing fact is that Dirck's father, Rembrant Dircksz, also shoemaker in Nieuwe Niedorp, was involved in a trial of many years with his neighbour, a baker, over an unpaid bill of 28 'stuivers' for one pair of shoes and one pair of mules. ${ }^{34}$

\footnotetext{
31 'Deze is Dirk Rembrantsz van Nierop, die onder het schoenen lappen zoo vast in de Hemels loop was, dat zyn kamertje, met Konstlinien doortrokken, te Florense zou staan, was het zo licht door de lugt te voeren, als de Kapel van Lorette'. De Hooghe, De Italiaansche waarzegger (1701) 4.

${ }^{32}$ Regional Archive Alkmaar, Judicial Archive Niedorp, inv. nr. 83: Kohieren van de 200ste penning (1622). The two villages Nieuwe Niedorp and Oude Niedorp gained city rights together as 'stede Niedorp', indicating a certain importance which is not reflected in the number of inhabitants.

33 'Ick heb wel eertijdts groote conversatie ghehadt met een seker Man die uyt het Noordeland van nieuwe Niedorp van gheboorte was / genaemt Reyer Dircksz / die my verhaelde van de eenvuldigheyd van het Volck in 't Noordt-Holland / hoe dat aldaer van oude tijden in het geheele Dorp van Lange-dijck niet meer als twee of drie paer schoenen waren / dewelcke ghespaert werden voor de Schepenen en Regenten van het Dorp / wanneer dat sy na den Haghe souden trecken / soo trocken sy die schoenen aen / ende doorgaens ginck het Volck met klompen' See: Jan Adriaensz Leeghwater, Kleyne Chronycke van Graft en De Rijp (Amsterdam, 1649), 26.

34 'Rembrant Dircksz Schoenmaker, eyscher contra Cornelis Jansz Usstes van Oude Niedorp, gedaechde om betalinghe ter somma van 28 st ter cause van een paer schoene \& een paer muijlen. Concludert condemnatie van dien cum expensis'. Regional Archive Alkmaar, Schepenrol Niedorp 1606.
} 


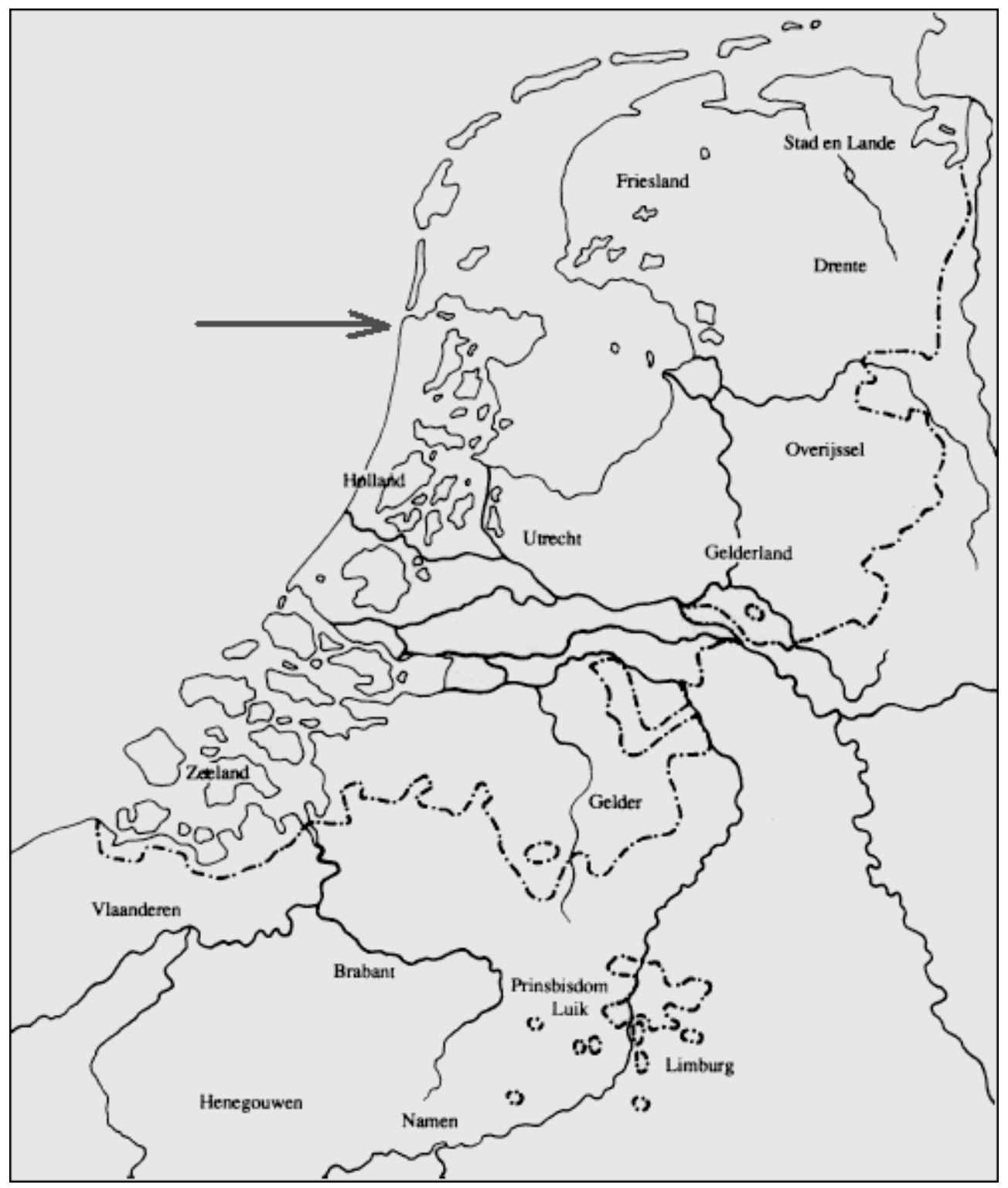

The location of Nieuwe Niedorp outlined on a map

of the Dutch Republic around 1650 


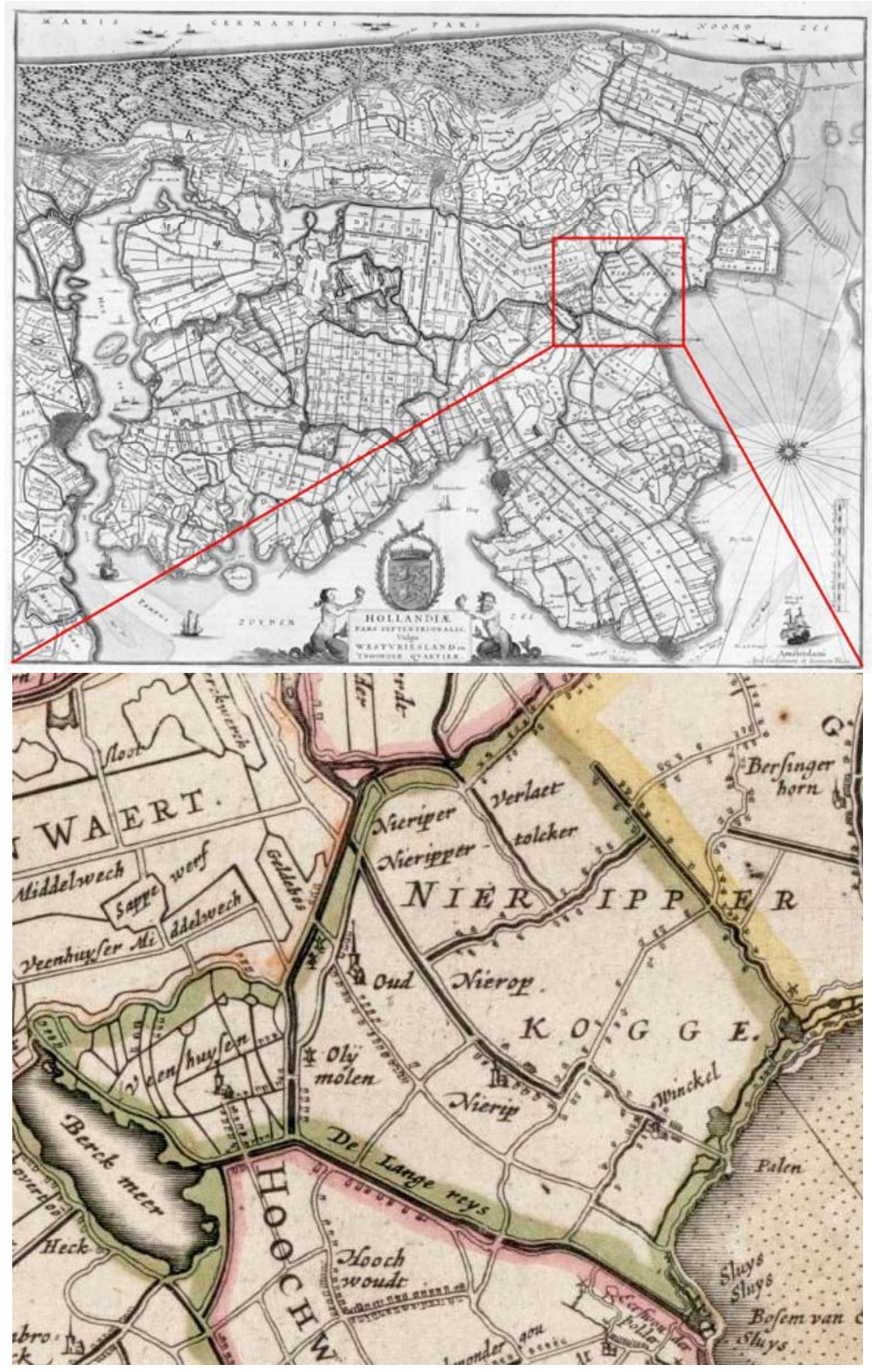

The location of Nieuwe Niedorp (or 'Nierop') outlined on a map

of 'Hollands Noorderkwartier', published by the

Amsterdam cartographers W.J. \& J. Blaeu in 1640 
Van Nierop's modest background is emphasized by many authors, but it is uncertain how much time he actually spend on making shoes after he started his career as navigation teacher and almanach maker. In the tax archives he is identified as both a shoemaker and astronomer. ${ }^{35}$ Also, Dirck and his brother were smallholders, owning a couple of cows. In his will ${ }^{36}$ (1678), we can read that he is a 'master and teacher in astronomy, mathematics, and navigation, ${ }^{, 37}$, while the profession as shoemaker is gone. ${ }^{38}$ His will shows that Dirck Rembrantsz died reasonably well to do; he possessed a house with an orchard, books and instruments, and bequeathed between 200 and 500 guilders to his nephews and nieces, while also donating 100 guilders to the poor people belonging to his 'eklelesie' (or church, which in his case was most likely the Mennonite Community). ${ }^{39}$ Finally, Van Nierop was able to order an impressive tomb stone for his grave in the - now disappeared (Reformed) church of Nieuwe Niedorp, which can still be seen in situ today.

Dirck Rembrantsz' social climb is exemplary for a growing group of people in the Dutch Republic, rising in social status because of their practical mathematical knowledge. The new social status stayed in the family together with the mathematical knowledge. The genealogy of the Van Nierop-Van Dam family shows a dynasty with several generations of practical mathematicians; the business of making Almanachs maintained in the family until the beginning of the nineteenth century. ${ }^{40}$ Van Nierop's nephew Pieter Cornelisz (Ooms) Rembrantsz van Nierop and nephew-by-marriage Albert Jansz van Dam were both taught by Dirck Rembrantsz. Later they worked themselves as surveyors and mathematicians. An outline of the Van Nierop-Van Dam Dynasty of mathematical practitioners, by

\footnotetext{
${ }^{35}$ For example in 1675: 'is een schoenmaker ende estronomist'.

${ }^{36}$ See below: Appendix: A-1.

37 '... de eersame dirck Rembrants, $\mathrm{m}^{\mathrm{r}}$. in de Astronomij, matematicus ende Stuermanschap'. Last will of Dirck Rembrantsz van Nierop, 1 November 1678. See this volume: 'Appendix' A-1.

${ }^{38}$ Although in earlier tax registration papers Van Nierop is indicated as shoemaker.

39 This can be found in the last will of Dirck Rembrantsz van Nierop and a list of heirs (Regional Archive Alkmaar). See this volume: 'Appendix' A-1 and A-3.

${ }^{40}$ Via Albert Jansz van Dam the family tradition was passed on from father to son until Meyndert van Dam (1730-1812). See below: Zuidervaart 'The Van Nierop \& Van Dam dynasty of mathematical practitioners'.
} 
Huib Zuidervaart, is included in this edition. The system of patents, granted from one generation to the next, ensured a family tradition of mathematical profession and a certain social status in the upcoming middle class of the Dutch Republic.

DIRCK REMBRANTS.

OUT ONTRENT 72 JAAR.

MR IN DE WISKONST.

HIER RUST DAT SCHRANDER HOOFT

DIE D'ECLIPS RECHT VERLICHTEN,

D'ASTRONOMI WIST TE STICHTEN.

SYN GLORIE NOOYT VERDOOFT.

HY TOOND ONS DAT DE SON

STIL STOND, D'AARTKLOOT DRAAYDE ${ }^{41}$

EN HOE DE DWAALDER SWAAYDE.

UYT WAARE WYSHEYTS BRON.

SCHOON MEENICH HIERMEE SPOT.

ZYN WYSER DER PLANEETEN

DOET ELCK D'WAARHEYD WEETEN

NU RUST SYN SIEL IN GOD.

DEN 4 NOVEMBER 1682.

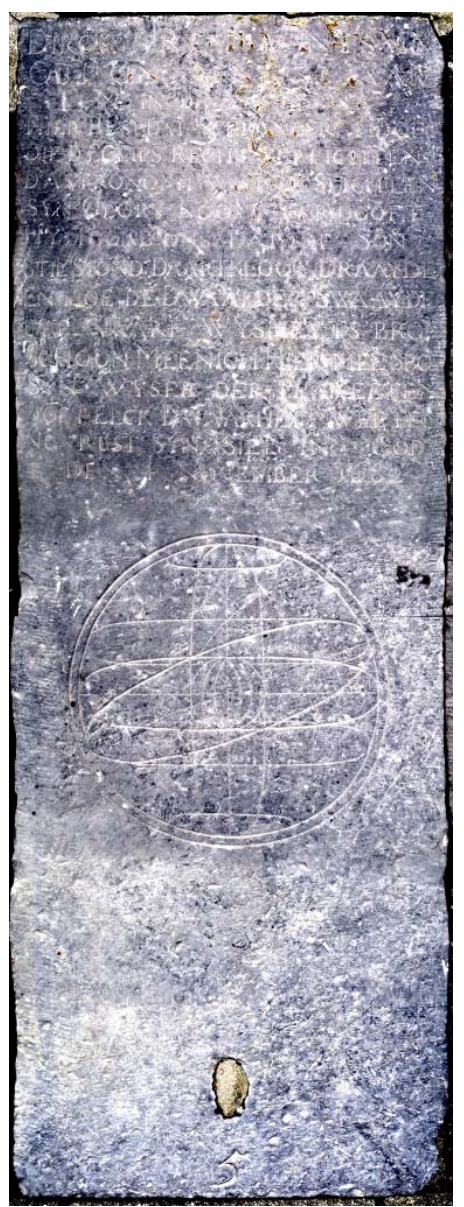

Dirck Rembrantsz' tomb stone with inscription from the former church Nieuwe Niedorp (1682), positioned since 1963 in the open air. The old church was demolished in 1875; a newer one in 1963

\footnotetext{
${ }^{41}$ In 1682 it was still remarkable that this heliocentric worldview was carved inside a church. In many reformed churches in the Netherlands, the Copernican world view was not accepted for a long time.
} 


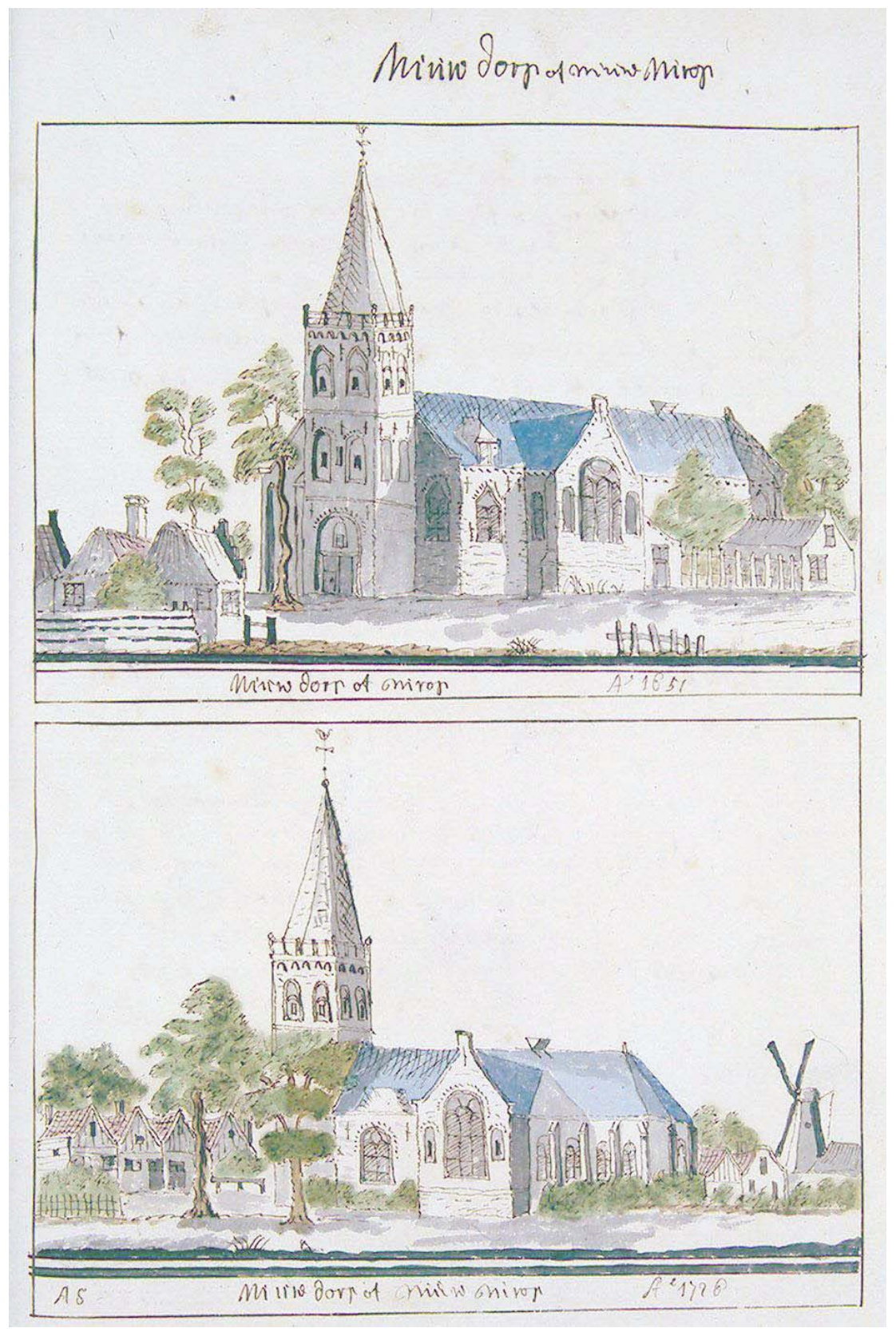

The old church in the village of Nieuwe Niedorp, ca. 1700

(Ms Schoenmaker, The Hague) 
Van Nierop's contacts with the rich and famous

Van Nierop's work was greatly influenced by the Descartes, as becomes immediately clear when comparing the similarities between their pictures. Van Nierop had been introduced to the Cartesian worldview by Descartes personally during the latter's stay in Egmond; no wonder Dirck often refers to the master in his correspondence and books. In Eenige oeffeningen (1669), for instance, Van Nierop writes that his knowledge of comets was taught to him by Descartes, 'dewelcke voor desen in my een groot licht geteelt heeft' ('who had enlightened me in this matter'). ${ }^{42}$ Despite his Cartesian worldview, Dirck Rembrantsz remained to work with the more traditional Euclidian mathematical approach instead of using Descartes' (algebraic) mathematics. The story of the meeting between Van Nierop and René Descartes - Van Nierop was sent away twice by Descartes' valets, because he was taken for a beggar - is illustrative and is therefore included in this edition (the original French text by Adrien Baillet and an English translation). ${ }^{43}$ Indeed it is very remarkable that a low-ranked shoemaker from a tiny village on the Dutch countryside was able to win the respect and affection of the 'rich and famous'. Baillet partly explains this fact in his comment that by the middle of the seventeenth century 'the most remote and obscure villages were hardly less fertile in the growth of philosophy, than the flourishing cities of commerce'. ${ }^{44}$

Van Nierop started his publishing career in 1653, when he was already 43 years of age. From the very start it is clear that his work was appreciated by scholars as Christiaan Huygens and the Leiden Professor of mathematics Frans van Schooten the younger. From Huygens' correspondence we learn that he already owned a copy of Van Nierop's Nederduytsche Astronomia, shortly after its publication in 1653, and that he used this book for his study on the shadows of the earth on the moon. ${ }^{45}$

\footnotetext{
${ }^{42}$ Dirck Rembrantsz van Nierop, Eenige oeffeningen (1669), 63. [Bibliography, nr. 19]. Van Nierop also mentions Descartes on page 9 .

${ }^{43}$ Baillet, La Vie de Monsieur Descartes (1691). See elsewhere in this volume.

44 ‘... fit connoître en ce têms là que les villages les plus reculez \& les plus obscurs n'étoient guéres moins féconds que les villes du Commerce le plus floristant pour cultiver la Philosophie'. Cf. Baillet, La Vie de Monsieur Descartes (1691).

${ }^{45}$ Christiaan Huygens to Frans van Schooten, 23 October 1653, Oeuvres Complètes, letter nr. 165; See also: Catalogue de vente in: Oeuvres complètes, vol 22 (1950), 615. The first edition of the Nederduytsche
} 
Also, Van Schooten corresponded with van Nierop that very year, and in 1654 he recommended Huygens to buy the first astronomical almanach issued by Van Nierop. ${ }^{46}$

Years later, in 1688, in a report concerning time measurement and the determination of longitude at sea, Huygens mentions that he used a 'Pascaert van Europa' (a chart map of Europe) made by Van Nierop. ${ }^{47}$ This concerned a sea map that Dirck Rembrantsz had designed in 1658 for the Amsterdam publisher Gerrit van Goedesbergh, who had transferred this map to his colleague Pieter Goos, as is revealed by a contract made up before an Amsterdam notary. ${ }^{48}$ In his report Huygens compared the results measured with his clocks to the longitudes estimated by navigators. For this comparison Huygens needed reliable observations and maps, and he decided to produce his own map of the coasts between Texel and the Cape of Good Hope. For this map he used as a benchmark Van Nierop's thirty year old European chart map (1658), obviously putting much faith in the quality of Van Nierop's work: 'The map, insofar the upper part is concerned, till 27 degrees

Astronomia (1653) is very rare today. The Short Title Catalogue Netherlands (STCN) refers only to two copies.

${ }^{46}$ Fr. van Schooten to Christiaan Huygens, 25 October 1654, Oeuvres Complètes, letter nr. 201.

${ }^{47}$ D. Rembrantsz van Nierop, Waßende graade paskaart vertoonende alle zeekusten van Europa. De geheele Middelandsche Zee, als oock ten Noordwesten, en Noordoosten so veer als ons tot noch toe bekent is, geteekent door D. Rembrantsz van Nierop, t' Amsterdam, by Pieter Goos, op het Water inde Vergulde Zeespiegel. Copy in the UBA - collection Koninklijk Aardrijkskundig Genootschap (LK-VI-4). See: Leerink, 'Een kaart van Dirk Rz. van Nierop' (1947) and Schliesser, 'Van Nierop's paskaart van Europa' (1997).

48 'Compareerde etc. d'eersame Gerrit van Ghoesberghen ende verklaarde also hij van eenen Dirk Rembrants van Nierop ontfanghen ofte bekoomen heeft sekere ghetekende kaart, omme deselve voor sijn comparants rekeningh en kosten te laten snijden ende in druk brenghen ofte anders dat de voorsz. Dirk Rembrantsz vermagh de voorsz. kaart wederom te neemen, dien volghende met Pieter Goos meede compareerende die t'selve mede was verklaarende gheaccordeert ende over een ghekomen te sijn ghelijk sij luijden doen bij desen namentlijck dat hij Gherrit van Goesbergen de voorsz. tekening aan hem Ghoos is overgheevende ghelijck hij deselve ontfangen heeft met de belofte deselve soo haast in druk te sullen uitghaan, als hem doenlijk sijn sal ende dat hij Gherrit van Ghoesberghen ende sijne erven de voorsz. kaart uijtkomende, sooveel exemplaren voor ieder afgesette exemplaar twee guldens. Mede verbinden zij zigh geen kaarten aan boekverkopers te verkoopen Voor minder dan twee gulden, tien stuivers 't stuck in gheldt en niet minder als drie gulden in rekening. (Notary C. de Ghrijp, Amsterdam, 17 July 1658). Published by Kleerkooper, De boekhandel te Amsterdam 1275-1276. See also Schliesser, 'Van Nierop's paskaart van Europa' (1997), 93. 
northern-latitude, is taken from a chart with cylindrical projection by D. Rembrandts van Nierop'. 49

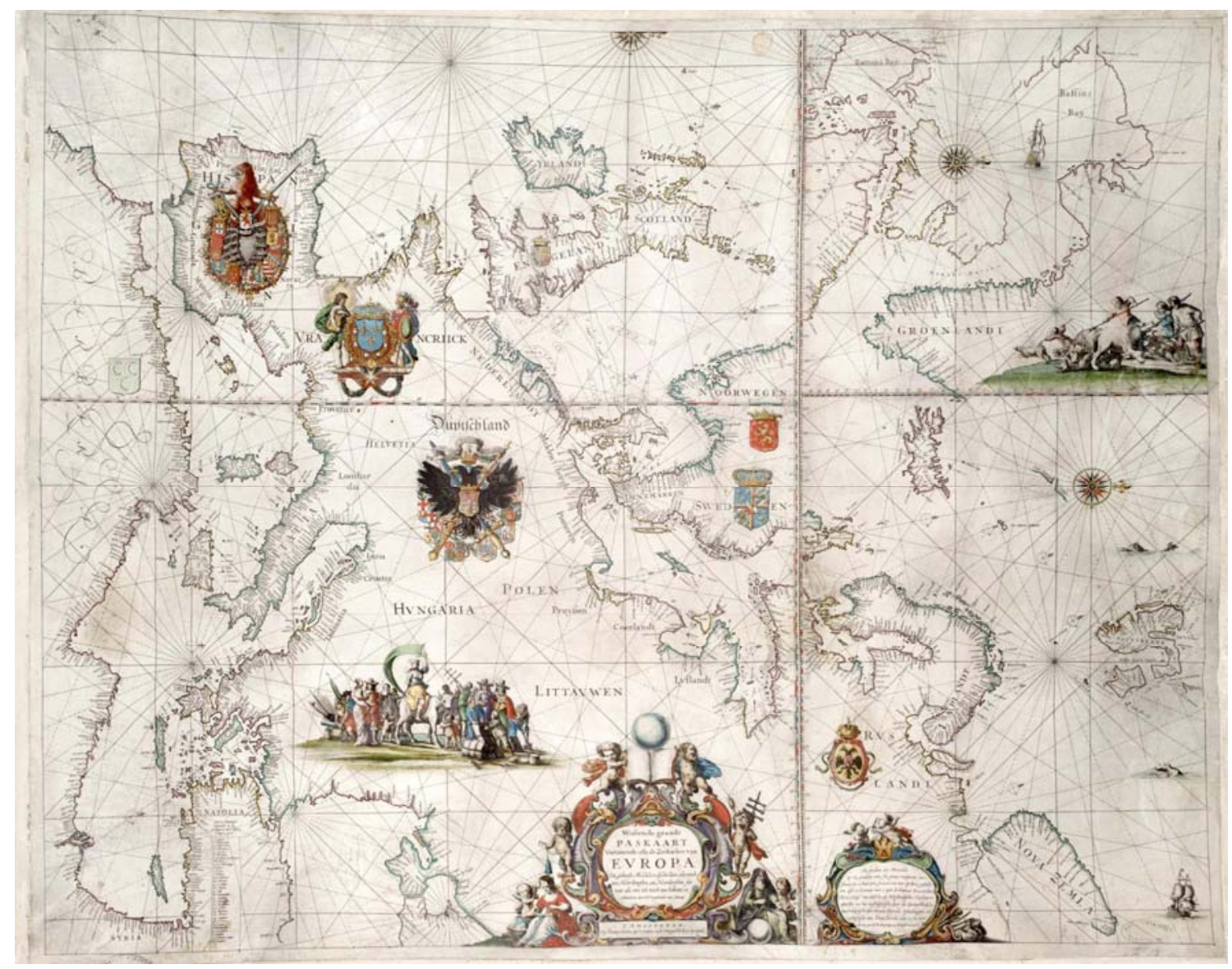

Dirck Rembrantsz van Nierop, Wassende graade paskaart (1658), used in 1688 by Chr. Huygens.

49 Christiaan Huygens to the Directors of the Dutch East India Company, 24 April 1688, Oeuvres Complètes, letter nr. 2519: 'De Caerte, voor soo veel het bovenste deel aengaet, tot op de 27 graden Noorder Breedte is genomen uijt een Pascaert van Europa met wassende graden van D. Rembrandts van Nierop'. In the same report, Huygens also writes: 'De Lengde tusschen Texel en Teneriffa heb ick gelaeten gelijck in de Caert van D. Rembrantz. sijnde van 22 graden'. Dirck Rembrantsz discussed the drawing method of this map in his Eenige Oefeningen (1669), 30-34. [See: Bibliography, nr. 19]. 
At some moment Christiaan Huygens actually visited Dirck Rembrantsz in Nieuwe Niedorp, together with his brother-in-law Philips Doublet. Another visit of the latter to the shoemaker-mathematician is mentioned in a letter from Huygens to Doublet, dated 18 June 1666: 'I thank you for [writing me] the details of your visit to D. Rembrantsz. I hope that the mood you found him in this time was normal, and that he felt bad when we were there together. ${ }^{50}$ From Huygens' book catalogue we know that he owned eight works by Van Nierop. ${ }^{51}$ From his preserved papers we know that he owned some handwritten copies of title pages of books by Van Nierop, apparently send to him in 1680 (most likely not by Van Nierop, perhaps by Doublet). At last, in July 1684 Christiaan mentions the death of Van Nierop in a letter to his brother Constantijn. ${ }^{52}$

Van Nierop corresponded with Huygens on the phenomenon of multiple parhelia (or sun dogs) in a letter in 1669, mentioning that he does not agree with Descartes on this matter. ${ }^{53}$ Descartes probably lacked observations of the phenomenon, which caused his misinterpretation according to Van Nierop. ${ }^{54}$ In the same letter, Van Nierop refers to an old (published) travel journal by Gerrit de Veer, in which the phenomenon is also described. De Veer kept a journal when he was a member of the famous Dutch expedition to find a northern passage to East India, which ended in the crew's forced stay on Nova Zembla in the winter of 15961596. On 4 June 1596 De Veer gives an account of false suns: 'on each side of the Sun there was another Sun, with two Rainbows through all three Suns, and two more Rainbows, the one wide around the Suns, the other through the large

${ }^{50}$ Chr. Huygens to Philips Doublet, 18 June 1666: 'Ie vous remercie des particularitez de vostre visite chez D. Rembrantz. Ie veux esperer que l'humeur ou vous l'avez trouvè cette fois est son ordinaire et qu'il se portoit mal lors que nous y fumes ensemble'. Oeuvres Complètes, letter nr. 1545.

${ }^{51}$ Nederduytsche Astronomia (1653); Een kort byvoeghsel op de Friesche sterre-konst (1654); Mathematische Calculatie (1659); Des Aertrycks beweging (1661); Eenige Oeffeninge (1669); By-voeghsel op de Nederduytsche Astronomia (1677); Byvoeghsel op des Aertrycks beweging (1677); Tweede deel op de Wiskonstige Rekening (1680). [Bibliography nrs. 1; 3; 12; 15; 19; 26; 27; 29]. See: website by Ad Davidse http://adcs.home.xs4all.nl/Huygens/22/cat-a.html.

${ }^{52}$ Chr. Huygens to Const. Huygens, July 1684: 'Je ne vous escris point les nouuelles d'icy. (...) Vous aurez aussi appris la mort de Mr. Nierop'. Oeuvres complètes, letter nr. 2356.

53 This edition letter nr. 39.

54 '... den heer Des Cartes zijn reden over dese dingen wat nader te overwegen: Waer in my dunkt dat hem voornamelyk de eijgen ondervindingen ontbroken hebben'. This volume, letter nr. 39. 
circle'. ${ }^{55}$ Another curious phenomenon described by De Veer was the early rise of the sun on Nova Zembla, today known as the 'Nova Zembla effect', which is a polar mirage, caused by the refraction of light, that seems to be a sunrise to the observer. Van Nierop's interest in this phenomenon resulted in his work Tweede deel van enige oefeningen in de geografie (1674). In the first part of this book he discusses the 'the early rise of the sun on Nova Zembla in the year 1597'. The second part concerns 'some comments on the travels north to East India. ${ }^{56}$ Van Nierop's reputation on this subject even reached England: a translation of the second part of this book was published that same year in the Philosophical Transactions. ${ }^{57}$

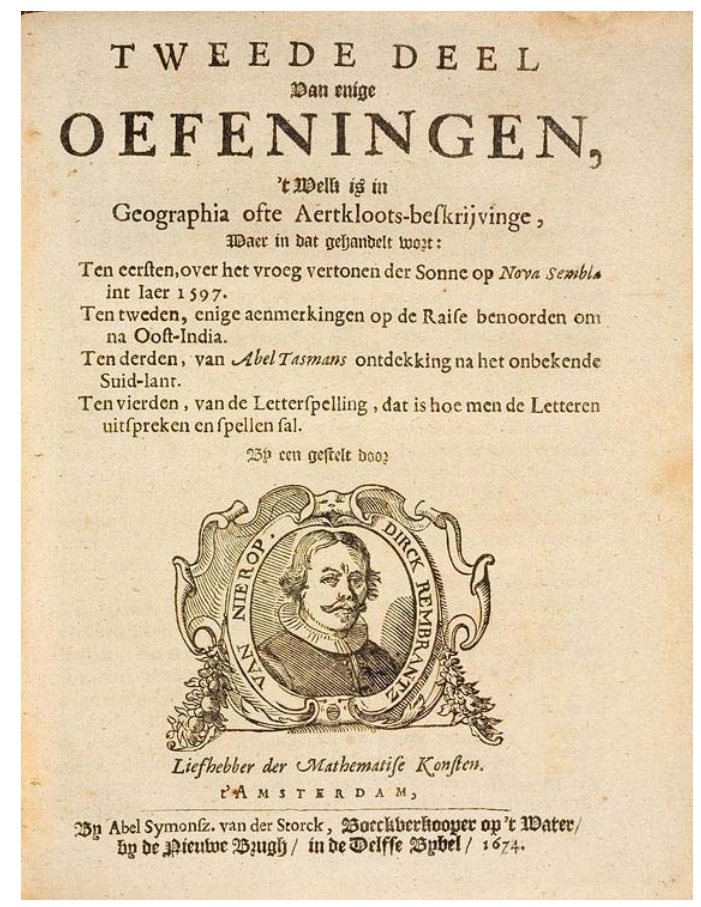

Frontespiece of Van Nierop's Tweede deel van enige oefeningen in de geografie (1674)

\footnotetext{
55 'Ontrent z.z.o. Son sagen wy een wonderlijck Hemel-teijcken, aende elcke zyde vande Sonne scheen noch een Son, ende daer liepen twee Reghenboghen deur alle de drie Sonnen henen, ende daer nae noch twee Reghenbogen, de eene wijdt rondtomme de Sonnen, ende de ander dweers deur de groote ronde, ende het groote rondt stont de onderste cant verheven boven den Horisont 28. graden'. De Veer, Waerachtighe beschryvinghe van drie seylagien (1598) 16v.

${ }^{56}$ See: 'Bibliography' nr. 23.

57 Philosophical Transactions (1674) 197.
} 
One eager reader of this very book was Nicolaas Witsen (1641 - 1717), who later in life would become a director of the Dutch East India Company and mayor of Amsterdam. In his young years Witsen stayed in Moscow in Dutch diplomatic service and he had been interested in the Russian steppes ever since. ${ }^{58}$ He started a correspondence with Van Nierop on 15 January 1679, after he had acquired a copy of Tweede deel van enige oefeningen. ${ }^{59}$ In the first letter Witsen writes about his stay in Moscow, and how he became curious when he heard about Nova Zembla and the rumours of a northern passage to East India. Witsen likes to hear Dirck's opinion on this matter and asks for information of the area. The letters between Van Nierop and Witsen mainly concern cartography and give an interesting insight in the 'networks of knowledge' that were used when producing maps: reports by sailors and travellers are discussed to determine sea routes around Nova Zembla. ${ }^{60}$ One of the 'eye-witnesses' mentioned is Lodewijk Fabritius (1648 - 1729), a Dutch envoy in Russian and Swedish service. ${ }^{61}$ Another person that is supposed to provide information on the geography of Nova Zembla is Jan Struys (1629 - 1700), a sailor and sail-maker from the Netherlands whose travels were later recorded in a bestselling travel journal. ${ }^{62}$ When looking at the letters exchanged between a Van Nierop and Witsen, we see that eye-witness reports played a fundamental part in geographical accounts and cartography. In 1681 Witsen announces a visit to Nieuwe Niedorp to show Dirck Rembrantsz his newly made map of Tartary and to

\footnotetext{
${ }^{58}$ For Witsen see: Peters, De wijze koopman. Het wereldwijde onderzoek van Nicolaes Witsen (2010).

59 The Witsen - Van Nierop correspondence is discussed in Peters, De wijze koopman (2010), 169171.

${ }^{60}$ See: 'Corpus', letters nr. 60-65 and 67-68. There is a map made by Van Nierop (1658) with the 'sea coasts' ('zeekusten) of Europe, including the coasts of Nova Zembla. Nicolaas Witsen published a map of Tartary in 1687.

${ }^{61}$ Lodewijk Fabritius was born in Brazil. He enlisted in the Russian army in 1660 and later was in service of the Swedes, where he was knighted in 1696. See: Eekman, 'Muscovy's international relations in the late seventeenth century. Johan van Keller's observations' (1992), 58; Glenn Cross, Russia under Western eyes (1971), 120, 383. Witsen wrote to Dirck Rembrandtsz about Fabritius: 'Deze Jongeman is voor 4 maanden van hier over Sweeden en Mosco naar Persien getrokken'. (Four months ago this Young-man has travelled via Sweden and Moscow to Persia.)

${ }^{62}$ Drie Aanmerkelijke en seer Rampspoedige Reysen (Amsterdam 1676), a book translated in multiple languages and became a bestseller in all Western Europe.
} 
ask for Dirck's opinion. ${ }^{63}$ Eventually Witsen lacked the time to go Nieuwe Niedorp and send his map together with a letter in 1682. Van Nierop did make a stop at Witsen's house in Amsterdam twice. Yet both these efforts were in vain, as he did not find the other at home. ${ }^{64}$ Again, it is demonstrated that the difference in social status was no barrier to the circulation of knowledge from persons of different backgrounds. The result of Witsen's curiosity was an extensive work on the lands of Tartary (nowadays northern Russia) Noord en Oost Tartarye published in 1692, twenty-five years after he had stayed in Moscow. In this book Witsen refers to Van Nierop's Tweede deel van enige oefeningen, concerning a possible northern sea passage from Asia to Europe; part of Van Nierop's work is literally adopted by Witsen. ${ }^{65}$

Another remarkable contact of Dirck Rembrantsz was the well-known Danzig astronomer Johannes Hevelius. Hitherto it was only known that the Leiden student of philosophy Abraham Boddens forwarded a letter by Hevelius to Van Nierop. ${ }^{66}$ Yet two - so-far unnoticed - letters between Van Nierop and Johannes Hevelius came forward in Paris; they are transcribed and included in this edition. Dirck had send a letter on 7 May 1677, asking Hevelius' opinion on the solar parallax; he wondered if Hevelius had read his chapter on this issue in Nederduytsche Astronomia. ${ }^{67}$ Hevelius answered he has not yet read Nederduytsche Astronomia

\footnotetext{
${ }^{63}$ Witsen to Van Nierop, 1 August 1681: 'Ik hebbe nog toe gene resolutie om deze kaarte in 't ligt te geven, doch egter wilse wel vertoonen, en zal zoo dra als ik in Noord Holland koome (dat gisse in 't najaar zal zyn, of misschien wel eer als wanneer ik in Commissie van deze Stad, wil God, tot Petten moet wezen) meede brengen, en by UE tot Nierop komen en vertoonen, om u oordeel daar over te verzoeken'. This edition, letter nr. 64. See also: Keuning, 'Nicolaas Witsen as a geographer' (1954), 98.

${ }^{64}$ In letter nr. 64 on 1 August 1682, Witsen writes to Van Nierop that he is honoured that Van Nierop has paid him a visit, and regretful that he was not home at the time. ('Het is my leet dat UE my de eer heeft gedaan van ten mynen huysen aan te komen, op een tyd dat ik juyst op het Raathuys was, indien ik doen geweten hadde waar UE te vinde waard geweest soude UE hebben gesogt, wanneer UE weder alhier mogte komen, verzoeke dat eens gelieft te hervatten'.)

${ }^{65}$ Witsen, Noord en Oost Tartarye (1692; second edition 1705). Witsen uses Van Nierop's account from the Tweede deel van enige oefeningen (1674) 42-48. See also letter nr. 65.

${ }^{66}$ For Boddens, see letter nr. 20.

${ }^{67}$ See 'Corpus', letter nr. 52. Solar parallax: the angle of which the Earth's mean radius would be seen from the centre of the Sun, or the difference in position of the Sun, as seen from the Earth's centre and from a point at one Earth radius away. Knowing the Solar Parallax and the mean Earth radius allows one to calculate the distance of the Earth to the Sun.
} 
because he is not familiar with the Dutch astronomical terminology; nevertheless he thanked Van Nierop for his book. He returns the favour by sending to Dirck 'diese wenige bletter von dem neulichen Cometen' (these few sheets on the new comets), which probably refers to Epistola ad Amicum de Cometa, anno 1677, Gedani observato (Letter to a Friend on the Comet of 1677, observed in Danzig). ${ }^{68}$ This small work of only four pages concerns observations of the comet, made on 24 April 1677. This is the rarest publication by Hevelius; in 1820 only three copies were known. Today, one copy can be found in the Utrecht University Library, which most likely belonged to Van Nierop. ${ }^{69}$

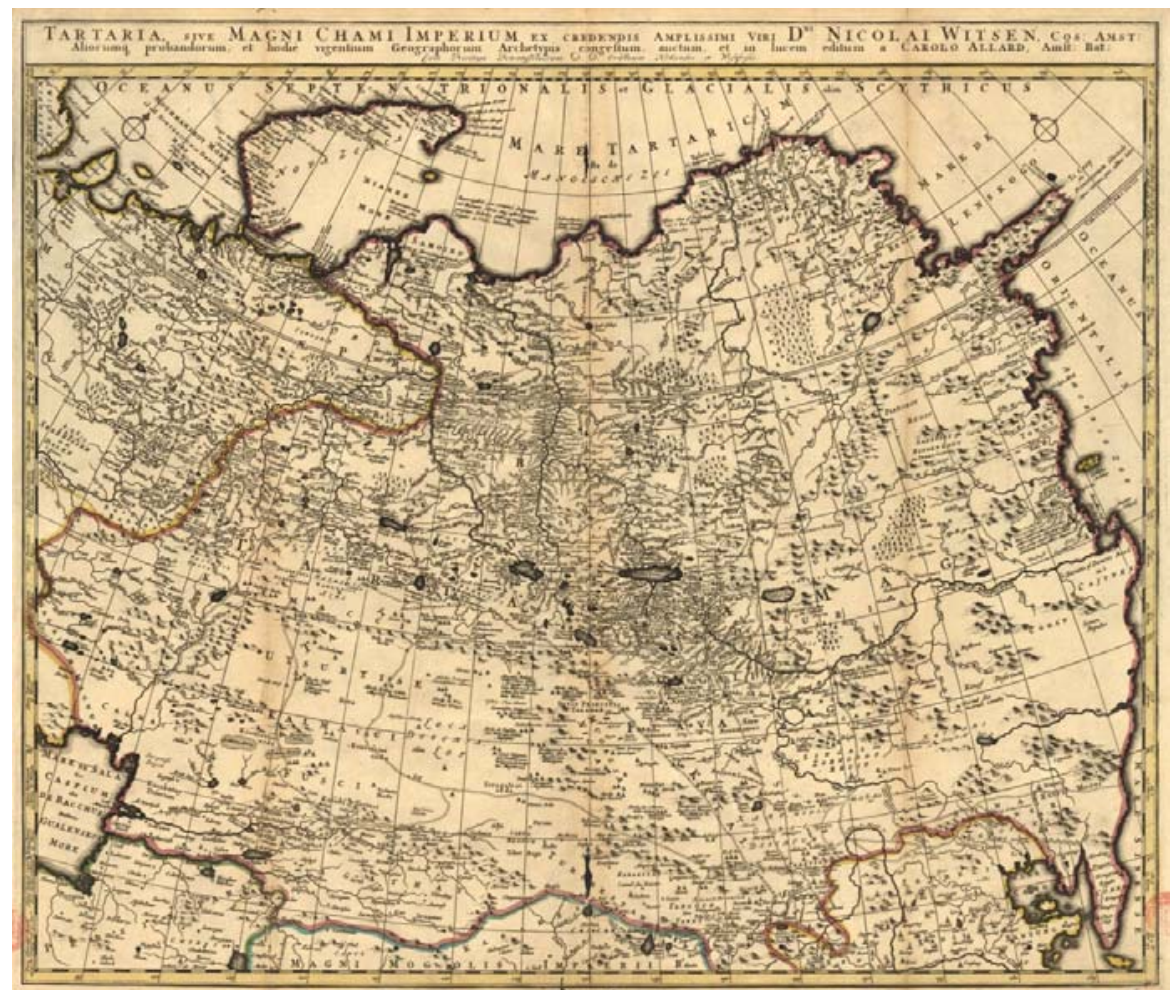

Nicolaas Witsen, Map of Tartary, 1705

\footnotetext{
${ }^{68}$ Johannes Hevelius, Johannis Hevelii Epistola ad amicum de cometa, anno M DC LXXVII, Gedani observato [1677].

${ }^{69}$ Unfortunately this copy does not contain any handwritten notes, not by Dirck Rembrantsz, nor by anyone else.
} 


\section{A local star in Holland}

Not much is known about Van Nierop's young years and the way he acquired his mathematical and astronomical knowledge. As mentioned before, he only started to publish in 1653 and the oldest remaining letter is from that same year. We do know, from his book Mathematische calculatie (1659), that he learned 'klootse' (spherical) trigonometry in 1632, at the age of 22 . He does not say who his teacher was, but from several books it is clear that he was influenced by Tade Philips, a surveyor and mill maker from nearby Schagen. According to Dirck Rembrantsz, Philips was an autodidact, who devised several mathematical problems, which were published by Van Nierop in his Mathematische calculatie of Wiskonstige rekening (1659) and his Tweede deel der wiskonstige rekening (1680). ${ }^{70}$ In his Nederduytsche Astronomia (1658) Dirck Rembrantsz also published some astronomical observations made in 1622 by Tade Philips. ${ }^{71}$

From the Mathematische calculatie of Wiskonstige rekening, it is evident that the family house in Nieuwe Niedorp burnt to the ground in 1639, in which event Van Nierop lost all his possessions, including a large multifaceted sundial, which he had constructed by his own hands, after an example in a book by Simon Stevin. ${ }^{72}$ Four years later, in 1643, he started again with the geometrical construction of sundials. Looking at both his correspondence and his books, we see that in the course of his life, Dirck Rembrantsz became a local star, not only in his home town, but in the Dutch Republic in its entirety.

In 1677 Van Nierop was honoured with a poem by Dirck Traudenius, one of his correspondents. Traudenius (c. 1607 - 1668) was the son of Johannes Traudenius, rector of the Latin School in Leiden. He matriculated three times as a student at Leiden University, in 1617, 1621 and the last time in 1653 at the age of 45. In the 1620s he lived for a while in West-Zaandam. From 1628 until his death in 1668 Traudenius acted as a notary in Leiden, while he also obtained some fame as

\footnotetext{
${ }^{70}$ Dirck Rembrantsz van Nierop, Mathematische calculatie of Wiskonstige rekening (1659), 143-167. Idem, Tweede deel wiskonstige rekening (1680), 97, 118, 137. [Bibliography nr. 29]. See also letters nr. 26 and 46.

${ }^{71}$ Dirck Rembrantsz van Nierop, Nederduytsche Astronomia (1658) 12. [Bibliography nr. 1]

72 Dirck Rembrantsz van Nierop, Mathematische calculatie (1659), 89. [Bibliography nr. 12]
} 
a poet. ${ }^{73}$ Traudenius and Van Nierop correspondended on chronology in 1664, a subject on which Traudenius had published a book in $1648 .^{74}$ In the preface to his Tijdt-Beschrijvinghe der Werelt (1654) Van Nierop states that he had used Traudenius work for his chapter on the 'Burgerlijcke tijdt' (Civil time). ${ }^{75}$ Traudenius poem praising the work of Van Nierop was published in Van Nierop's Byvoeghsel op des Aertryks beweging (1677).

Dus schiep de handt des Konstenaars 't beeldt

Van Dirck, die Kerck noch Raedthuys streelt;

Maer, ront van hert, de Werelt wijst

Hoe d'Aerdt-kloot loopt en daelt en rijst.

Wie buyght sich voor dien Lynceus niet,

Die door en door den Hemel siet,

En soo veel knoopen kan ontwerren,

Ten roem van Gode, in Son en Sterren!

D. Traudenius ${ }^{76}$

Poems and doggerels were used by mathematical practitioners - as was common among various groups of people until the end of the eighteenth century - for various reasons: as a means to pose mathematical questions, but also to honour, criticize or insult someone. Another example of an honouring poem was published by Jan Albertsz van Dam, the son of Van Nierop's nephew-by-mariage Albert Jansz van Dam. In this poem, published in the preface of a manual for sea pilots (De Nieuwe Hoornse Schatkamer), the great authority of the families Van Nierop and Van Dam is emphasized: 'aanhoor het onderwijs, van 't zaad uyt Rembrants Stam |

\footnotetext{
73 In 1661 he offered a poem to Constantijn Huygens. See: Worp (ed.), Constantijn Huygens, Briefwisseling 5 (1916), nr. 5717.

${ }^{74}$ Dirck Traudenius, De Nederduytsche tyd-zifter. Dat is: Kort tractaet van de onderscheydinge ende afdeelinge van den tyd (Zanerdam: H.J. Zoete-boom / Amsteldam: T. Houthaak, 1648). See also this volume, letter nrs. 31 and 32 .

75 Dirck Rembrantsz van Nierop Tijdt-Beschrijvinghe der Werelt (1654), preface and page 154. [Bibliography nr. 2]

${ }^{76}$ Dirck Rembrantsz van Nierop, Byvoeghsel op des Aertryks beweging (1677) 2. [Bibliography nr. 27].
} 
Wiens groot geslagt zig spreyd van Nierop tot van Dam' ('listen to the instruction, from the offspring of Rembrant's clan | Of whom a great family is expanded from Nierop to van Dam').

Just as Dirck and his successors, many of his correspondents in the province of Holland were mathematical practitioners, and worked as surveyors, cartographers or lens-grinders, or were 'liefhebbers' (lover-amateur) of the mathematical arts. One of these 'liefhebbers' was Bartholt van Steenhuysen Boelens (1628 - 1669), regent in Alkmaar. In a letter from Van Steenhuysen to Van Nierop in 1663, we read that Steenhuysen thanks Dirck for lending him some sundials and books. ${ }^{77}$ In Tweede deel op de wiskonstige rekening (1680) Van Nierop not only mentions their correspondence a few times, but also included problems raised by Steenhuysen Boelens concerning the use of sundials and the mathematics of weight. ${ }^{78}$ This is but one example of the circulation of knowledge demonstrated by looking at both Dirck Rembrantsz' correspondence and publications. ${ }^{79}$ After his death, Bartholt van Steenhuysen Boelens left a library which shows his mathematical and astronomical interests. From an advertisement in the 'Opregte Haerlemsche Courant', we know that he left various mathematical and astronomical books. ${ }^{80}$ Unfortunately, the auction catalogue is missing, so we do not know which books by Van Nierop were in Van Steenhuysen's collection.

\footnotetext{
${ }^{77}$ Bartholt van Steenhuysen Boelenz (Alkmaar) to Dirck Rembrantsz van Nierop (Nieuwe Niedorp), 13 October 1663: 'Goede Vrient Dirk Rembrantsz, hier nevens zende UE wederom toe de Zonnewysers met de Boeken, voor wiens gebruyk ik UE hertelyk bedanke'. This edition: letter nr. 27.

78 Dirck Rembrantsz van Nierop, Tweede deel op de wiskonstige rekening (1680): the letters are mentioned on pages 165 and 167, the problem is raised on page 112 .

${ }^{79}$ Except the persons appearing in his preserved correspondence, Dirck Rembrantsz van Nierop also refers to issues submitted by 'Jan Pietersz Bakker van Wormerveer'; 'Mr. Gerrit E. Bakker, schoolmeester tot Graft'; 'Mr. Albert van Deem'; Tijs Fransz Kistemaker en 'Mr Maerten Swaen, Schoolmeester tot Ulpendam' [=Ilpendam $]$.

80 'Op den 23 Iuly 1670, zijnde Woensdagh, 's Morgens ten 9 uren, sullen tot Alckmaer verkocht werden de naegelaten Boecken van den E: Heer Bartholdus van Steenhuysen, in sijn leven Raedt en President van Schepenen der Stadt Alckmaer;bestaende in verscheyde Faculteyten, soo Theologische, Juridici, Misselanische, Mathematische en Astronomische Boecken; waer van de Catalogi by verscheyden zijn'. Opregte Haerlemsche Courant, 19 July 1670.
} 


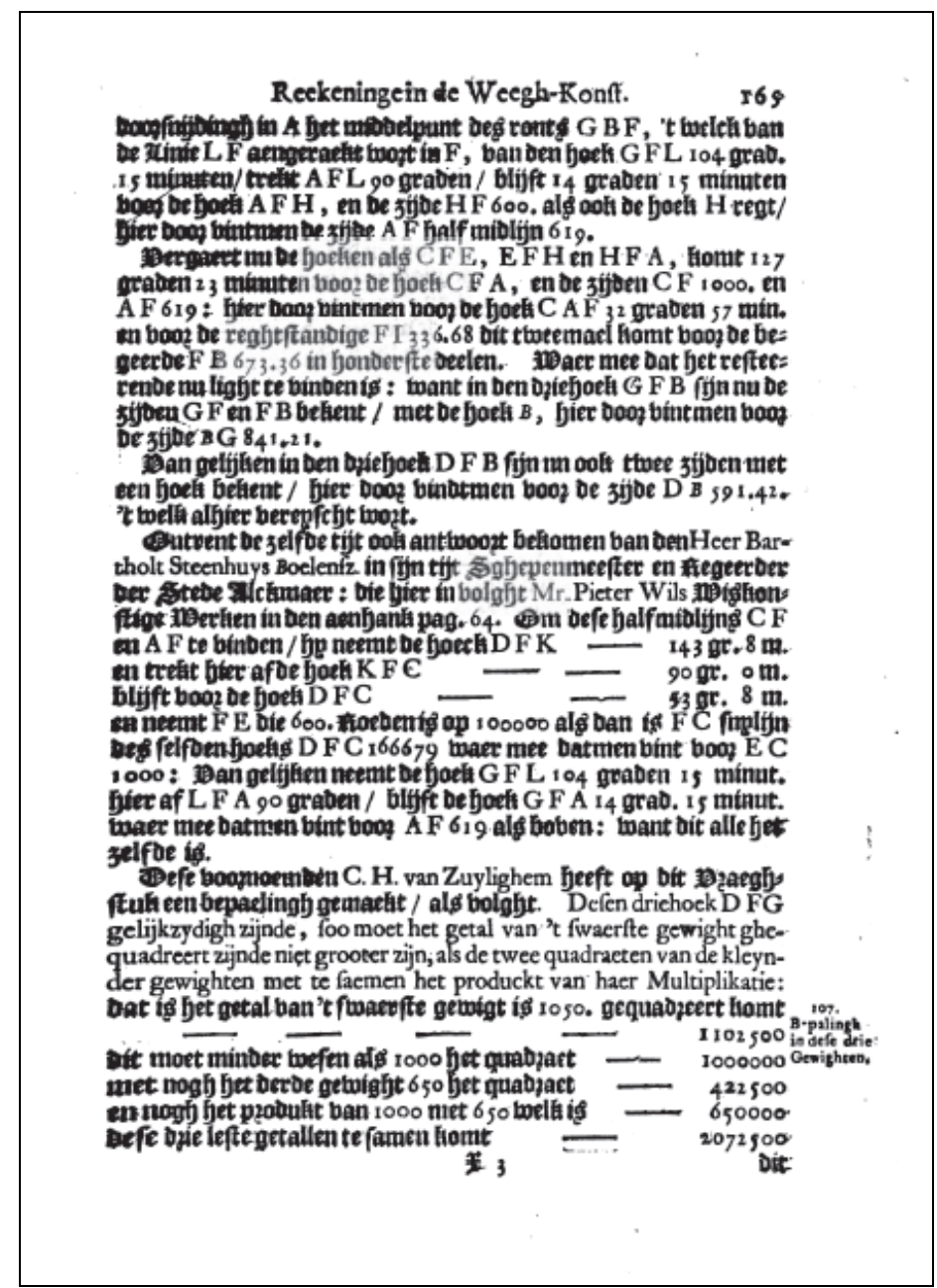

Tweede deel op de wiskonstige rekening (1680), page 165

Van Nierop refers to the letter by Steenhuysen Boelens on the mathematics of weighing

Baltsar Adriaansz (? - 1694) was a lens-grinder in Graft, a small village near Alkmaar (in Alkmaar a large group of telescope makers was active ${ }^{81}$ ) and received a letter by Van Nierop in 1678. In this letter Van Nierop gives advice how best to observe the phases of Venus. He adds: 'I have announced this to more amateurs and lensgrinders, as it happens only once every eight years that this planet approaches the

${ }^{81}$ See: Zuidervaart, 'The 'invisible technician' made visible. Telescope making in the seventeenth and early eighteenth-century Dutch Republic' ( 2012). 
sun with rising signs' ${ }^{82}$ This letter shows that Van Nierop had a certain interest in observations, as did some local amateurs and craftsmen. Baltsar Adriaansz apparently was an informed and interested amateur, as Van Nierop included 'a question proposed by Baltsar Adriaansz, lens-grinder in Graft' (about finding the polar height) in Tweede deel op de wiskonstige rekening (1680). ${ }^{83}$

Despite the mainly geometrical character of Van Nierop's work, there is some evidence of him doing actual observations. In Eenige oeffeningen (1669) he describes his observations of the comets of 1664 and $1665 ;{ }^{84}$ in the Tweede deel op de wiskonstige rekening (1680) he writes about observations of the planet Mercury, performed in April 1674, together with his nephew Pieter Rembrantsz, while he also mentions that in 1671 'some of his disciples' have done observations on the path of the Sun for the determination of the polar height. ${ }^{85}$

The reception of Van Nierop's works

In the eighteenth century Van Nierop has been given much credit, for instance by people like François Valentyn, Nicolaas Struyck, or Jacob Oostwoud (on whom more below). According to Valentyn, The States of Holland had requested Van Nierop to use a large telescope to observe the moons of Jupiter, apparently to test a theory for determining the longitude at sea. ${ }^{86}$ Struyck refers to the work of Dirck Rembrantsz concerning comets and eclipses and his reputation as almanach maker. According to Struyck, already in 1642 Van Nierop had found ways to calculate

\footnotetext{
${ }^{82}$ Translation by Vermij, 'Correspondence'.

${ }^{83}$ Dirck Rembrantsz van Nierop, Tweede deel op de wiskonstige rekening (1680) 86.

${ }^{84}$ Dirck Rembrantsz van Nierop, Eenige oeffeningen (1669), 67, 70. Van Nierop also refers here to observations made in 1665 by the surveyor Jacob Brasser of Hoorn.

85 Dirck Rembrantsz van Nierop, Eenige oeffeningen (1669) 67; Idem, Tweede deel op de wiskonstige rekening (1680) 23, 31.

${ }^{86}$ Valentyn, Oud en nieuw Oost-Indiën (1724) 118: 'te dier tyd aan Dirk Rembrantsz van Nierop zoo sterk bevestigde, dat die bewoogen wiert met een groote kyker eenige waarnemingen hier op te doen'. According to Valentijn this theory had been proposed by Descartes, but it it questionable if this test happened at all. The idea of using the Jupiter moons as a clockwork for determining the longitude at sea was proposed in 1634 to the States General of the Dutch Republic by Galileo Galilei, but the method appeared useless at sea. See: Davids, Zeewezen en wetenschap (1985).
} 
Sun-Eclipses. ${ }^{87}$ In the nineteenth century there was some interest in Van Nierop by professors G. Moll and U.G. Lauts, of whom the latter wrote a small biography of Van Nierop. ${ }^{88}$ In the early twentieth century G.W. Wolthuis published an article wherein he discusses the play by Pieter Langendijk and the charges of plagiarism and ignorance that divided the mathematical community in the second half of the seventeenth century. ${ }^{89}$ Wolthuis decisively takes sides with De Graaf against Van Nierop (and Van Leeuwen), claiming that De Graaf, more than others, stuck to mathematical arguments. ${ }^{90}$ The quarrel between Van Nierop and De Graaf, in which other pupils and correspondents of Van Nierop were involved too, was just one example of the tensions between mathematicians, as Vermij has pointed out'.

The vast majority of Van Nierop's correspondence is available today thanks to the efforts of the eighteenth-century mathematical teacher Jacob Goverts Oostwoud (1714 - 1784). Jacob was living in more-or-less the same region as Van Nierop. According to his own statement Oostwoud acquired the letters through his father, the mathematician Govert Maartensz Oostwoud (1671 - 1723). ${ }^{92}$ How Govert received these letters is not known, but we can make an educated guess. Oostwoud Sr. worked as a schoolteacher in Hem, a small village very close to the city of Hoorn. According to a family chronicle, Govert started his career in 1693 as a sailor; a career that ended quickly, as he was shipwrecked on his first journey, near the coast of France. ${ }^{93}$ Before his leave, Govert had acquired some formal training in the 'Reken- Meet-, Stuurmans- en Hemelloopkunde' (calculus, geometry, navigation

\footnotetext{
${ }^{87}$ Struyck, Vervolg van de Beschrijving der Comeeten (1753) 132: 'Dirk Rembrantsz van Nierop heeft in 't Jaar 1642 reeds manieren gevonden om de Zon-Eclipsen in ' $t$ algemeen uit te rekenen'. See also page 32 and 180.

${ }^{88}$ Lauts, 'Levensberigt van Dirk Rembrandtsz van Nierop' (1843). Dirck Rembrandtsz van Nierop was mentioned as excellent teacher of navigation and astronomer by Moll, Verhandeling over eenige vroegere Zeetogten der Nederlanders (1825) 188, 195. (In the Special Collections of the Amsterdam University library, shelfmark OTM: hs. $31 \mathrm{Cv}$, there is a copy of this paper, with handwritten notes by Lauts).

${ }^{89}$ Wolthuis, 'Pieter Langendijk en de wiskunstenaars (1936).

${ }^{90}$ Ibidem, 246.

${ }^{91}$ See: Vermij, The Calvinist Copernicans (2002) 198-204.

${ }^{92}$ See Vermij, 'Correspondence' (1996) 51.

${ }^{93}$ For the Oostwoud family, see: Honig, 'Jacob Oostwoud' (1932).
} 
and astronomy) by Pieter Warius, a well known notary, school master and mathematical author, living in Govert's birth town Oostwoud, not far from Nieuwe Niedorp. During that time Govert already must have heard some stories about Dirck and his nephew Pieter Rembrantsz van Nierop. After his return in the Netherlands, Govert became a school master and instructor for sea pilots in Hem, remarkably after he had collected a recommendation for this job in England, from king-stadtholder Willem III of Orange. After his appointment Govert published a navigational handbook Schoole der Stuurlieden (1701). He also worked as a surveyor and cartographer. So Govert Oostwoud was a direct colleague of Pieter Rembrantsz van Nierop and Albert Jansz van Dam, in nearby Hoorn. Through them, at some moment in time, he must have had access to the correspondence. It seems plausible that Govert had borrowed the letters before Pieter Rembrantsz' death in 1708. As Govert himself died in 1713, leaving his young son Jacob orphaned at the age of nine, the Van Nierop correspondence must have remained unnoticed between Govert's papers for many years. Only decades later in 1731, when Govert's youngest son followed his late fathers footsteps, Jacob must have stumbled across the papers between his fathers legacy by mere chance.

In 1736 Jacob Oostwoud was appointed schoolmaster and teacher of mathematics in Oost-Zaandam. During those years Jacob corresponded with Nicolaas Struyck, whom he also provided with the numbers of inhabitants of many villages in the north of Holland for Struyck's chapter 'Eenige aanmerkingen op de gissingen over den staat van het menschelijk geslagt', in his book Algemeene Geographie (1740). ${ }^{94}$ Jacob also acquired fame with the publication of a journal for mathematics teachers, Mathematische Liefhebberye, met het maandelijkse nieuws der Fransche en Duytsche schoolen in Nederland ('Mathematical pastimes, with the monthly news of the French and German Schools in The Netherlands'), published in Purmerend from 1754 onwards. ${ }^{95}$ Oostwoud published Van Nierop's letters in this

\footnotetext{
${ }^{94}$ In 1769, after Struyck's death, Oostwoud would receive from Struycks estate a legacy of one thousend guilders, as a token of his gratitude for Oostwoud's assistance. Cf. Honig, 'Jacob Oostwoud' 16.; Zuidervaart, 'Konstgenoten' (1999), 211; idem, 'Early Quantification of Scientific Knowledge: Nicolaas Struyck (1686-1769) as Collector of Empirical Gathered Data' (2002) 140.

95 Jacob Oostwoud (ed.), [Maandelykse] Mathematische Liefhebberye, met het Nieuws der Fransche en Duytsche Schoolen in Nederland (Purmerend 1754-1776). The letters were published in volumes 3 to 10. A complete copy of this rare periodical can be found in the Special Collections of Amsterdam University Library.
} 
journal, next to all kinds of mathematical problems (sometimes in rhyme). Copies of this periodical are extremely rare today. Only three (partly incomplete) copies are preserved in Dutch university libraries in Amsterdam, Leiden and Delft. By the end of his life Oostwoud was honoured with a membership of the Wiskundig Genootschap ('Mathematical Society') in Amsterdam). ${ }^{96}$ After his death his accomplishments were praised in a poem, while his son published some of his father's works posthumously.
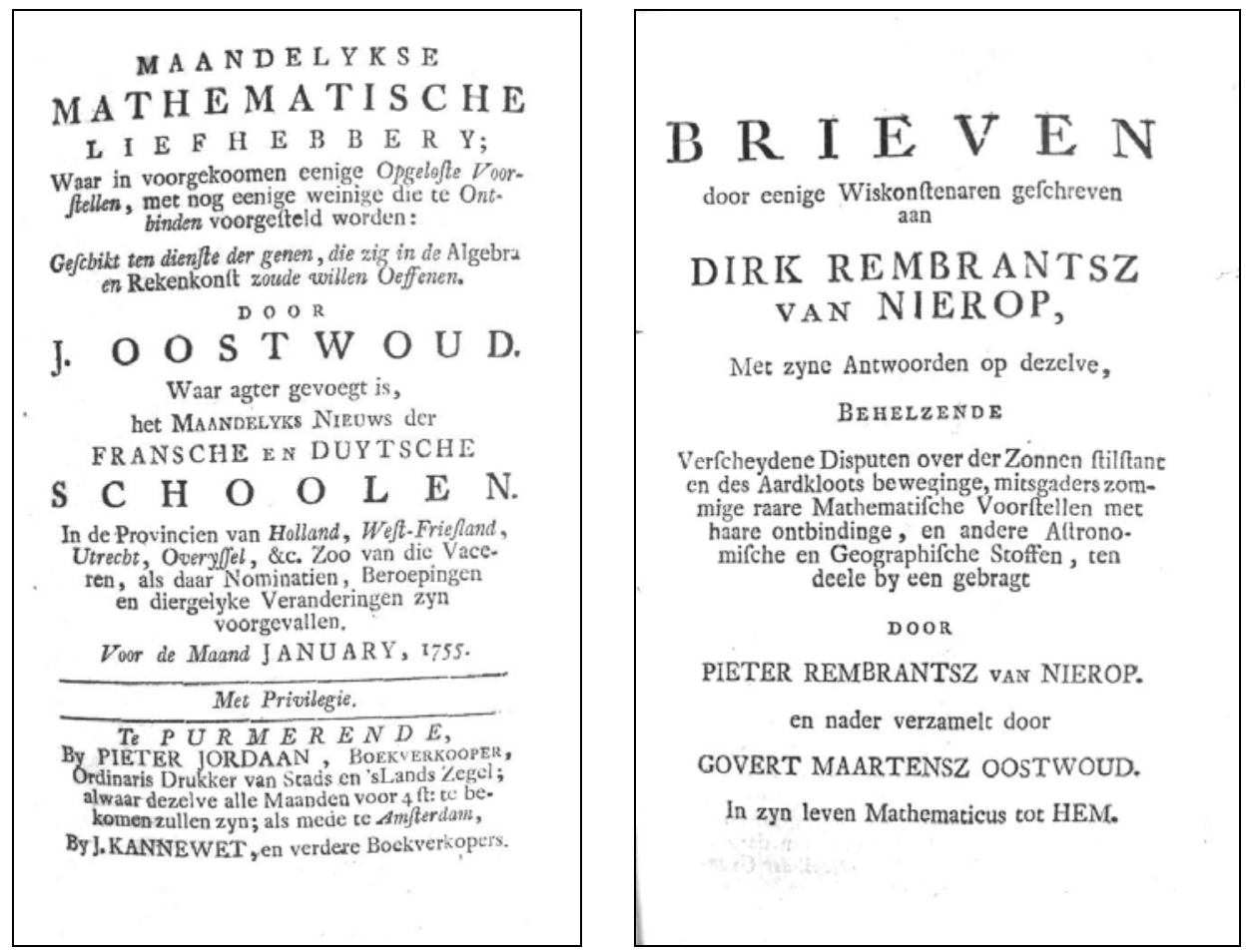

Title pages from Oostwoud's Maandelykse Mathematische Liefhebbery, with the opening page of Dirck

Rembrantsz' correspondence, collected by Pieter Cornelis Rembrantsz Ooms (c. 1640 - 1708) and Jacob Oostwoud's father Govert Maartensz Oostwoud (1671 - 1723)

\footnotetext{
${ }^{96}$ Honig, 'Jacob Oostwoud' 26. The full name of this society was: Genootschap der Mathematische Weetenschappen onder de Sprenk: Een Onvermoeide Arbeid Komt Alles te Boven. Oostwoud was also a member of the Kunstrechnungsliebender Societä $t$ in Hamburg (Germany).
} 


\section{This edition}

This new edition of 79 letters by - or to - Dirck Rembrantsz van Nierop makes these letters accessible for a much wider audience. ${ }^{97}$ In order to shed more light on Van Nierop's correspondents we have included a re-edition of the paper by Rienk Vermij, entitled 'Correspondence of Dirk Rembrantszoon van Nierop'. This paper was published before in 1996 and is included here with the authorisation of the author. $^{98}$ Two so-far unnoticed letters between Van Nierop and Johannes Hevelius are transcribed and published below. Another 'forgotten' letter from Van Nierop to Nicolaas Witsen is also included; this letter was only published in the 1692 edition of Witsen's Noord en Oost Tartarye. ${ }^{99}$ The corpus of letters is followed by an appendix, with some deeds and charters from archives relating to the legacy of Dirck Rembrantsz. Included is also: an inventory of all known letters (with correspondents and sources); the account by Adrien Baillet of the meeting between Descartes and Dirck Rembrantsz; an extensive bibliography of Van Nierop's published works composed by Klaas Hoogendoorn; an outline of the dynasty of mathematical practitioners in the Van Nierop and Van Dam family by Huib Zuidervaart; and an index of persons. The letters in this edition are numbered anew. They are chronologically ordered and freshly annotated. Part of the annotation in the Mathematische Liefhebberye and the Oeuvres Complètes is adopted. Biographical information of persons can be found in a note the first time a person is mentioned. In line with the corpus composed by Jacob Oostwoud, four letters by Albert Jansz van Dam are also included. ${ }^{100}$ Finally, the spelling of the name 'Dirck Rembrantsz van Nierop' is chosen, because this is the spelling most often used in the contemporary sources.

In the course of 2012-2013 digital transcriptions of Van Nierop's letters will be included in the open source project 'Circulation of Knowledge Collected Corpora' (CKCC), by the Huygens ING. This database of scholarly correspondence

\footnotetext{
${ }^{97}$ Number of remaining letters per decade: $1650 \mathrm{~s}-15 ; 1660 \mathrm{~s}-28 ; 1670 \mathrm{~s}-15 ; 1680 \mathrm{~s}-19$. Total of 79 letters, excluding the four letters by Albert Jansz van Dam.

98 Vermij, 'Correspondence of Dirk Rembrandtszoon van Nierop' (1996).

${ }^{99}$ Witsen, Noord en Oost Tartarye (1692).

100 Albert Jansz van Dam had married Dirk's niece, see 'The Van Nierop and Van Dam Dynasty'.
} 
will be completely searchable and provide newly developed tools for advanced analyses of networks and concepts.

\section{Acknowledgements}

This publication could not have been realized without the support of the Huygens ING (KNAW). I would like to thank my colleagues at the Huygens ING for their helpful suggestions, motivating discussions, and good company. I am indebted to Huib Zuidervaart for his enthusiasm and trust in this project, and for the outline of the Van Nierop-family and Van Dam dynasty. Further, I owe gratitude to Rienk Vermij for allowing his article to be re-published in this edition; to Klaas Hoogendoorn for his excellent bibliography of Van Nierop's works; to KlausDieter Herbst for his help with the transcription of a German handwriting by Hevelius; to Ilja Nieuwland for the cover design; to Walter Ravenek for his help with the digital transcriptions and the forthcoming digital publication; to Annet Klomp-Keuken for kindly sharing her documents collected in the Regional Archive Alkmaar.

The Hague, March 2012 